\title{
Interest Rate Pass-Through in Three EU Candidate Countries: The Case of Albania, North Macedonia and Serbia
}

\author{
Igor Velickovski (Corresponding author) \\ National Bank of the Republic of North Macedonia \\ Kuzman Josifovski Pitu 1, 1000 Skopje, Republic of North Macedonia \\ Tel: 389-23-108-401 E-mail: velickovskii@nbrm.mk; \\ University American College Skopje \\ School of Business Economics and Management, Treta Makedonska Brigada 60, 1000 \\ Skopje, Republic of North Macedonia \\ Tel: 389-22-463-156 E-mail: velickovski@uacs.edu.mk \\ Daniela Mamuchevska \\ Ss. Cyril and Methodius University in Skopje, Faculty of Economics - Skopje \\ Blvd. Goce Delcev 9V, 1000 Skopje, Republic of North Macedonia \\ Tel: 389-23-286-866 E-mail: danielam@eccf.ukim.edu.mk
}

Received: August 30, 2019 Accepted: September 30, 2019 Published: October 2, 2019

doi:10.5296/ieb.v5i2.15362 URL: https://doi.org/10.5296/ieb.v5i2.15362

All the opinions expressed in this article are those of the authors and do not necessarily reflect the views of the National Bank of the Republic of North Macedonia, the University American College Skopje and the Ss. Cyril and Methodius University in Skopje, Faculty of Economics - Skopje.

\section{Abstract}

The objective of the paper is to assess the interest rate pass-through in three EU candidate countries that is Albania, North Macedonia and Serbia. We rely on an error-correction model using monthly data over the period 2005-2019. Results suggest a complete interest rate pass-through in Albania, albeit it has been weakened during the economic and financial crisis. 
The relatively fast speed of adjustment indicates an effective interest rate transmission channel. In the Macedonian case, the changes of the monetary policy rate are transmitted completely to the bank lending rate, but not to the bank borrowing rate. The transmission via the money market rate has improved after the global economic and financial turmoil. In the case of Serbia, the results also suggest complete interest rate pass-through indicating that the monetary policy rate changes are transmitted into retail rates offered by the banks to savers and borrowers in the long run. Nevertheless, the speed of adjustment is relatively slow. In general, the estimated speed and extent of the response of money market interest rate and bank retail interest rates to changes in the monetary policy rate gives an indication of effective interest rate transmission channel in the case of Albania and Serbia. On the other hand, it is moderately effective in the case of North Macedonia given that the central bank rate changes affect mainly bank lending rate but not borrowing rate.

Keywords: Interest rate pass-through, Error-correction model, Central bank, Banks

\section{Introduction}

The Western Balkan countries are in different stages of the negotiation process for joining the European Union. North Macedonia was the first country from the Western Balkan to be granted European Union candidate status in 2005, followed by Serbia in 2012 and Albania in 2014. Serbia already opened the negotiation process with European Union in 2014, while Albania and North Macedonia expect to receive approval to start this process in 2019. Although their willingness to join the European Union is undoubted, it will still take some time before they gain full membership. In meantime, during the transition process which started in the early 90's these three countries have been conducting an independent monetary policy to some degree. Albania and Serbia adopted floating exchange rate regime allowing higher flexibility for the monetary policy in terms of shock absorption. On the other hand, North Macedonia has followed pegged exchange rate regime for more than two decades, which in combination with capital controls has enabled certain degree of independent monetary policy (Note 1 ).

In this context, the interest rate pass-through is very important issue in terms of assessing the ability to conduct an independent monetary policy. Central banks use various instruments to influence money market rates. Their changes, in turn, are transmitted into retail rates offered by the banks to savers and borrowers. Albania, North Macedonia and Serbia are bank-based economies in which banking is the dominant source of financing and therefore, the retail interest rates determined by the banks may substantially affect the consumption and investment decisions made by households and firms. Thus, the extent and speed of transmission of monetary policy rate changes is particularly relevant to policy decisions taken by the central banks of Albania, North Macedonia and Serbia.

Given the limited research for these three countries, our paper contributes to the interest rate pass-through literature by assessing in an error-correction framework, the extent and speed of adjustment of money market and retail rates to monetary policy rate changes during the recent period. Furthermore, by using data from 2005 until 2019 we examine how stable the interest rate pass-through is considering possible structural shifts driven by the global economic and financial crisis. 
The rest of the paper is organized as follows. The next section reviews the literature; Section 3 explains the data, methodology and estimation approach; Section 4 discusses the empirical results; and the final section concludes the paper.

\section{Literature Review}

Interest rate pass-through is an important issue for central bankers in evaluating the efficiency of a country's banking system. Many studies estimate certain pass-through coefficients that describe the banks' interest-setting behaviour. They aim to investigate whether there are price rigidities and incomplete pass-through behavior, such that central bank interest rate and money market interest rate changes are not directly reflected in adjusted bank interest rates. Thus, the estimation of how bank interest rates react to changes in central bank or money market interest rates is motivated by the aim of analyzing how well banks perform as financial intermediaries. Moreover, the extent and speed to which changes in funding costs are passed on to bank customers should be known by monetary authorities (De Bondt, 2005; Liu et al., 2008; Rosen, 2002; Sander \& Kleimeier, 2004; Wang \& Lee, 2009).

Rousseas (1985) proposed a simple theoretical model for interest rate pass-through assuming perfect competitive markets. In this context, bank lending rates would change one-to-one with the monetary policy rate resulting in a complete pass-through. However, this assumption is often violated in practice because the banking and financial market structures show rather monopoly or oligopoly behavior of banks (firms). Hefferman (1996) also emphasized that imperfect market competition is responsible for the dynamics of retail interest rates. Therefore, an incomplete pass through could be expected. Also, Sørensen and Werner (2006) argued that the varying degrees of competition in the banking sector are responsible for limited bank interest rate pass-through. In addition, regulations on interest rate ceilings, costs that are associated with adjustments, bank exposure to interest rate risks, credit risks, and the long-term relationships between banks and their customers are possible factors for lag adjustment of bank interest rates (Kwapil \& Scharler, 2006). Holton and d'Acri (2015) focusing on the euro area banks, report a significant effect of credit risk on the interest rate pass-through. Moreover, Kapuściński and Stanislawska (2018) suggest that money market interest rates may not be a sufficiently good proxy for banks' funding costs, especially in the periods of increased financial stress and for analyses of the transmission of negative interest rates.

Several studies find that the interest rate channel has the most prominent role in comparison with other monetary channels (exchange rate channel, credit channel and asset prices channel) in the euro area (Angeloni et al., 2003; McAdam \& Morgan, 2001). Since the financial crisis of 2008, literature has switched the interest to compare the pass-through between pre financial crisis and after financial crisis period. Hristo et al. (2014) found that the pass-through was obstructed during the period from 2008 to 2011, indicating that monetary policies were distorted during the after financial crisis period. On the other hand, Borstel et al. (2016) evaluated the bank lending rates pass-through in 11 euro members and estimated that the interest rates pass-through didn't have significant change during the 2008 financial crisis period. Paries et al. (2014) estimate for the four largest euro area countries (Germany, France, Italy and Spain) that downward adjustments in policy rates and market reference rates translated into an associated reduction in bank lending rates. In the case of Spain and Italy, 
however, sovereign bond market tensions and a deteriorating macroeconomic environment have put upward pressure on composite lending rates to non-financial corporations and households. Results show incomplete pass-through of changes in money market rates targeted by the central bank to firms' lending rates, with increases in sovereign bond yields affecting the cost of finance for firms, particularly in stressed countries. A useful survey on the empirical literature on the retail bank interest rate pass-through in the euro area countries is provided by Andries and Billon (2016).

Focusing on the determinants of interest rate pass-through, Gigineishvili (2011) finds that per capita GDP, inflation, exchange rate flexibility, credit quality, and banking competition strengthen the pass-through, whereas market volatility and excess banking liquidity impede it. The latter is particularly important for transition countries, including Albania, North Macedonia and Serbia, since most of them implement monetary policy in structural surplus of liquidity. The amount and scope of research on the interest rate transmission channels in Albania, North Macedonia and Serbia is relatively limited given that most of the earlier studies focused mainly on exchange rate channel (Billmeier and Bonato, 2002; Krstevska et al., 2003; Vilaret \& Palić, 2006; Istrefi \& Semi, 2007; Tanku et al., 2007; Tasic, 2008; Besimi, 2009).

Regarding the interest rate channel, Kolasi et al. (2010) estimated statistically significant effects of interest rates on inflation, but not on output of Albania, while Aleksić et al. (2008) found very weak role of interest rates in influencing inflation and output in Serbia. As for the interest rate pass-through, Velickovski (2013) finds that the pass-through from a change of the central bank rate to the banks' lending rates is relatively high in Macedonia and Albania, but lower in Serbia. Malile (2013) investigates the asymmetry of interest rate pass-through in Albania and shows that the pass-through of monetary policy rate to wholesale and retail interest rates is asymmetric. More specifically, the wholesale rates and the deposit rate react more strongly to a negative change rather than to a positive change in policy rate. Miletic and Tasic (2015) suggest that there is a significant long run relationship between bank lending rates and money market rates in Serbia. However, interest rate pass-through appears to be incomplete for both corporate and household lending rates.

Given the limited research done for Albania, North Macedonia and Serbia, we aim to enrich the empirical literature on interest rate pass-through for these three EU candidate countries since we are interested in how both money market and bank rates respond to changes in the monetary policy rate.

\section{Methodology, Data and Estimation Approach}

The multivariate approach is followed in investigating the interest rate pass-through in Albania, North Macedonia and Serbia, since it can detect more than one cointegrating relationship and estimate the long-run relationships and short-run dynamic in one step (Johansen, 1995). The following error-correction model is considered:

$$
\Delta Z_{t}=\mu_{2}+\delta_{0} T+A \Delta Z_{t-i}+\alpha\left[\begin{array}{l}
\beta_{1} \\
\mu_{3} \\
\delta_{1}
\end{array}\right] Z_{t-1}+\omega_{t}
$$




\section{Macrothink}

where $Z$ denotes the vector of endogenous variables (monetary policy interest rate, money market interest rate, bank borrowing interest rate and bank lending interest rate), $\mu_{2}$ and $\delta_{0}$ are, respectively, an unrestricted intercept and trend in the error-correction model, $T$ is a time trend, $A$ is a matrix of coefficients measuring short-run effects, $\alpha$ is a matrix of coefficients measuring speed of adjustment to equilibrium, $\beta_{1}$ denotes the matrix of long-run coefficients, $\mu_{3}$ and $\delta_{1}$ are, respectively, the restricted intercept and trend in the cointegating vector, and $\omega$ is the error term.

This analysis will use monthly data for interest rates obtained from Bank of Albania, National Bank of the Republic of North Macedonia and National Bank of Serbia. The investigated period starts in January 2005 for Albania and North Macedonia, while for Serbia it begins in October 2010 due to unavailable data for earlier period. The end of the investigated period is May 2019. In order to avoid the problem of spurious regression, unit root testing is necessary. Before proceeding to formal tests of stationarity, the data is plotted for visual inspection. Figure 1 shows that all interest rates are trending downward, albeit showing different degree of variability, indicating possible non-stationarity of the data since the mean and variance do not appear to be constant.

Albania

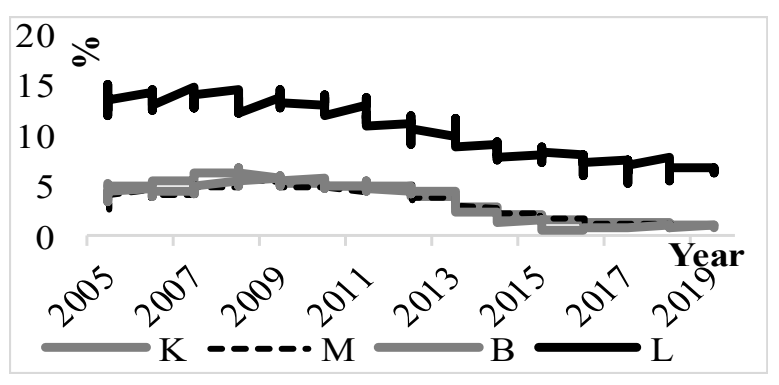

Serbia

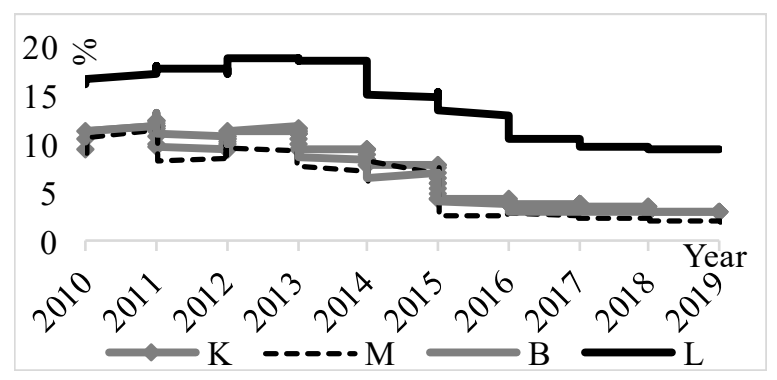

North Macedonia

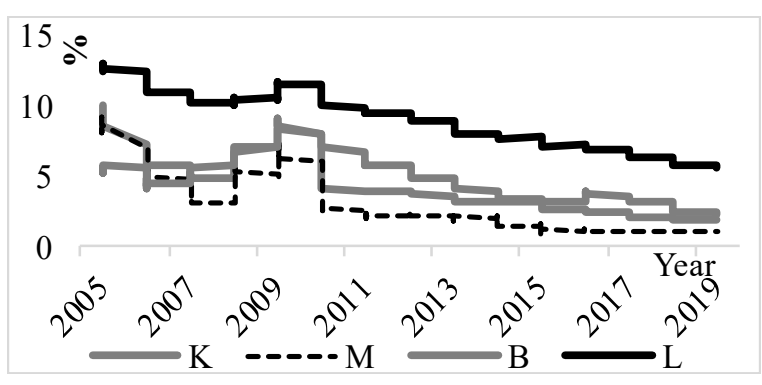

K-monetary policy interest rate; M-money market interest rate; B-bank borrowing interest rate; L-bank lending interest rate.

Figure 1. Movement of interest rates in three EU candidate countries

As for the formal stationarity tests, the ADF test is applied with and without trend. The number of lags included in the model is selected according to the Akaike and Schwartz criteria. The results from the ADF tests uniformly indicate that the null hypothesis of a unit root cannot be rejected for all investigated variables in levels (Table 1). On the other hand, 
the results robustly suggest that the data in first differences is stationary at the five percent level of significance for all tests conducted. Thus, the overall conclusion is that the data in levels is I(1), that is integrated of order one, which is convenient for the further analysis of applying the error-correction model.

The investigation of interest rate pass-through will rely on a simple two-step generalized least squares estimator, because Bruggemann and Lütkepohl (2005) note that the generalized least squares estimator has better small sample properties than Johansen's maximum likelihood estimator, which is important in this analysis given that it relies on a relatively small sample. In order to obtain a better specified model, a subset model is specified which allows restrictions to be imposed on the short-run parameters and on the adjustment parameters. The subset model is appropriate for the elimination of insignificant coefficients following the "Top-down" procedure in JMulTi (Note 2).

Table 1. Unit root tests for the levels of the variables (p-value)

\begin{tabular}{|c|c|c|c|c|c|c|c|}
\hline \multirow{2}{*}{$\begin{array}{l}\frac{0}{0} \\
\frac{\pi}{\tilde{J}} \\
\frac{\pi}{\pi}\end{array}$} & \multirow[b]{2}{*}{ Test } & \multicolumn{3}{|c|}{ Without trend } & \multicolumn{3}{|c|}{ With trend } \\
\hline & & Albania & $\begin{array}{l}\text { North } \\
\text { Macedonia }\end{array}$ & Serbia & Albania & $\begin{array}{l}\text { North } \\
\text { Macedonia }\end{array}$ & Serbia \\
\hline \multirow[t]{2}{*}{ K } & ADF-Akaike & 0.386 & 0.109 & 0.874 & 0.381 & 0.469 & 0.445 \\
\hline & ADF-Schwartz & 0.958 & 0.143 & 0.773 & 0.765 & 0.147 & 0.445 \\
\hline \multirow[t]{2}{*}{$\Delta \mathrm{K}$} & ADF-Akaike & 0.000 & 0.000 & 0.016 & 0.000 & 0.001 & 0.007 \\
\hline & ADF-Schwartz & 0.000 & 0.000 & 0.000 & 0.000 & 0.000 & 0.000 \\
\hline \multirow[t]{2}{*}{ M } & ADF-Akaike & 0.852 & 0.103 & 0.708 & 0.554 & 0.426 & 0.122 \\
\hline & ADF-Schwartz & 0.852 & 0.103 & 0.858 & 0.554 & 0.426 & 0.122 \\
\hline \multirow[t]{2}{*}{$\Delta \mathrm{M}$} & ADF-Akaike & 0.000 & 0.001 & 0.000 & 0.000 & 0.005 & 0.000 \\
\hline & ADF-Schwartz & 0.000 & 0.001 & 0.000 & 0.000 & 0.005 & 0.000 \\
\hline \multirow[t]{2}{*}{$\mathrm{B}$} & ADF-Akaike & 0.328 & 0.827 & 0.691 & 0.261 & 0.587 & 0.961 \\
\hline & ADF-Schwartz & 0.843 & 0.969 & 0.542 & 0.779 & 0.855 & 0.647 \\
\hline \multirow[t]{2}{*}{$\Delta \mathrm{B}$} & ADF-Akaike & 0.024 & 0.024 & 0.001 & 0.008 & 0.008 & 0.005 \\
\hline & ADF-Schwartz & 0.000 & 0.000 & 0.000 & 0.000 & 0.000 & 0.002 \\
\hline \multirow[t]{2}{*}{$\mathrm{L}$} & ADF-Akaike & 0.816 & 0.874 & 0.962 & 0.270 & 0.315 & 0.097 \\
\hline & ADF-Schwartz & 0.781 & 0.874 & 0.962 & 0.270 & 0.416 & 0.097 \\
\hline \multirow[t]{2}{*}{$\Delta \mathrm{L}$} & ADF-Akaike & 0.000 & 0.000 & 0.000 & 0.000 & 0.001 & 0.000 \\
\hline & ADF-Schwartz & 0.000 & 0.000 & 0.000 & 0.000 & 0.000 & 0.000 \\
\hline
\end{tabular}

Computed in EViews 7. 


\section{Results}

The important step in the cointegration analysis is specifying the lag order of the underlying VAR model since it may influence the determination of the cointegration rank and consequently the estimation of coefficients of the model. Lütkepohl and Krätzig (2004) discuss that selecting an unnecessarily large lag order may cause distortion of the power of the tests while choosing a low lag length may lead to size distortions of coefficients. Therefore, in searching for the appropriate lag length we rely on the information criteria. They often indicate different lag lengths. In this case, the results for three out of five criteria suggest two lags for Albania, five lags for North Macedonia and six lags for Serbia (Appendix 1).

The cointegration analysis in the multivariate context requires to determine the cointegration rank. When testing for the cointegation rank, the question of whether an intercept and/or trend should be included in the VAR (variables in first differences) and the cointegration vector (variables in levels) is raised. Regarding the specification of deterministic terms, Harris and Sollis (2003) note that three models can be realistically considered: i) Model 1 the intercept is restricted to the cointegration relations and there is no trend; ii) Model 2 -unrestricted intercepts (in the VAR and the cointegration space) and no trend; iii) Model 3 unrestricted intercepts (in the VAR and the cointegration space) and restricted trend to the cointegration vectors. In our case, it seems that the model 1 is more appropriate given we employ interest rates in our analysis and we do not expect that they drift only in one direction (upward or downward over time), since they fluctuate in both directions due to the business cycle changes. Thus, it is not expected to have linear trend in the levels of the data that is the first differences of the series have a zero mean leading to the restriction of the intercept to the cointegration vector. Nevertheless, other two models are not eliminated a priori and results from the tests are also considered.

Since four endogenous variables are investigated in our model, the cointegration rank should be in a range between zero and three. Two tests of cointegration rank are available in JMulTi 4: the Johansen test and the Saikkonen and Lütkepohl test. As shown in Appendix 2, all three countries reported a minimum cointegration rank of 1 for both tests, implying that the null hypothesis of no cointegration relationships among central bank interest rate, money market interest rate, bank borrowing interest rate and bank lending interest rate could be rejected at the 5\% significance level. According to the Johansen test, all three models for Albania suggest two cointegration vectors, while the Saikkonen and Lütkepohl tests suggest one cointegrating vector at the 5 percent level of significance; albeit some of the tests suggest higher number of cointegrating vectors at 10 percent level of significance. Therefore, we proceed the analysis with two cointegrating vectors. Regarding Macedonian and Serbian data, almost all of the tests suggest one and three cointegrating vectors at the 5 percent level of significance, respectively. Given the results from the cointegration rank tests and the discussion above, the cointegration analysis is based on model 1.

The estimation procedure in a cointegration context relies on specifying the order of the variables such that the first ordered variable in each cointegrating vector is selected for normalisation. Since the cointegration tests for the three countries suggest different number 
of cointegration vectors as presented above, we have to choose several variables for normalisation. Economic reasoning suggests the following order of normalisation: the bank lending interest rates to be normalized firstly, then banks borrowing interest rates, followed by money market interest rates since it is expected that the central bank interest rate influences the money market rates which transmit the changes to bank borrowing rates that finally as main funding costs affect the bank lending rates.

The diagnostics are checked before interpreting the results. Two tests for residual autocorrelation and normality are presented in Appendix 3. The LM test for residual autocorrelation does not reject the null of no residual autocorrelation at the 5 percent level of significance for the models of all three countries. On the other hand, the Jarque-Bera test suggests that non-normality is present in each model. The diagnostics do not improve significantly upon inclusion of longer lags. Nevertheless, the sample size in our models (173 observations for Albania and North Macedonia and 104 observations for Serbia) is substantially larger than the minimum number of observations in small sample (30), thus we believe it makes hypothesis testing fairly reliable. Therefore, in the next step the results of the model described in the Section 3 are discussed.

The estimated results for all three countries are presented in Table 2. Regarding the results for Albania, the coefficient of the bank lending interest rate is normalized to 1 in the first cointegrating vector, which means that this variable can be treated as dependent and all other variables as independent. The positive sign on the coefficient on the monetary policy interest rate is according to a priori expectations. The coefficient is statistically significant at 5 percent level of significance and suggests that one percentage point increase of the central bank interest rate gives 2.22 percentage points increase in the bank lending interest rate in the long run, ceteris paribus. However, the coefficient value is higher than one which might be result of the relatively short time series that capture a particular stage of the business cycle. This may have also affected the coefficient value of the money market interest rates which has a negative sign and is not according to a priori expectations. In the second cointegrating vector the coefficient of the bank borrowing rate is normalized to 1 . The coefficient on the money market interest rate is statistically significant with correct sign suggesting that one percentage point increase of the money market interest rate increases the bank borrowing interest rate by 1.03 percentage points in the long run, ceteris paribus. The coefficient on the central bank interest rate is not significant at any conventional level of significance. Regarding the adjustment coefficients measuring the speed of establishing the long-run equilibrium, they are statistically significant in both cointegrating vectors. Thus, the adjustment parameter in the first cointegrating vector in the equation where the change in bank lending rate is the dependent variable indicates that it adjusts by 41.8 percent of the remaining disequilibrium each month to establish long-run equilibrium. The adjustment coefficient in the second cointegrating vector in the equation where the change in bank borrowing rate is the dependent variable, indicates that it adjusts by 14.9 percent of the remaining disequilibrium each month to establish long-run equilibrium.

The estimations for North Macedonia suggest one cointegrating vector, where the coefficient of the bank lending interest rate is normalized to 1 . The coefficient on the monetary policy interest rate is statistically significant at 5 percent level of significance with positive sign and 
suggests that one percentage point increase of the central bank interest rate results in 1.07 percentage points increase in the bank lending interest rate in the long run, holding other things constant. The coefficients on the money market interest rate and bank borrowing interest rate are not significant at any conventional level of significance. The adjustment coefficient entering the equation where the change in bank lending interest rate is the dependent variable, indicates that it adjusts very slowly by 1.9 percent of the remaining disequilibrium each month to establish long-run equilibrium.

In the case of Serbia, three cointegrating vectors are estimated and thus, we normalise on bank lending interest rate, bank borrowing interest rate and money market interest rate. The estimated coefficients on the central bank interest rate suggest complete pass-through given that they are a little bit over one in all three cointegrating vectors which is not statistically different from one at the 5 percent level of significance. The speed of adjustment parameter from the first cointegrating vector entering the equation where the change in bank lending interest rate is the dependent variable, indicates that it adjusts by 9.9 percent of the remaining disequilibrium each month to establish long-run equilibrium. The adjustment coefficient in the second cointegrating vector in the equation where the change in bank borrowing interest rate is the dependent variable, indicates that it adjusts by 18.5 percent of the remaining disequilibrium each month to establish long-run equilibrium. The adjustment parameter in the third cointegrating vector is not statistically significant.

Table 2. Results from the cointegration analysis of interest rate pass-through

\begin{tabular}{|c|c|c|c|c|c|c|}
\hline \multirow{2}{*}{ Country } & \multirow{2}{*}{$\begin{array}{l}\text { Order of } \\
\text { cointeg. vector }\end{array}$} & \multicolumn{4}{|c|}{ Endogenous variables } & \multirow[t]{2}{*}{$\begin{array}{l}\text { Speed } \\
\text { adjust. }\end{array}$} \\
\hline & & $\mathrm{K}$ & M & B & $\mathrm{L}$ & \\
\hline \multirow[t]{2}{*}{ Albania } & First & $\begin{array}{l}2.223 \\
(0.000)\end{array}$ & $\begin{array}{l}-0.878 \\
(0.002)\end{array}$ & - & 1 & $\begin{array}{l}-0.418 \\
(\Delta \mathrm{L}) \\
(0.000)\end{array}$ \\
\hline & Second & $\begin{array}{l}0.096 \\
(0.602)\end{array}$ & $\begin{array}{l}1.033 \\
(0.000)\end{array}$ & 1 & - & $\begin{array}{l}-0.149 \\
(\Delta \mathrm{B}) \\
(0.000)\end{array}$ \\
\hline $\begin{array}{l}\text { North } \\
\text { Macedonia }\end{array}$ & First & $\begin{array}{l}1.078 \\
(0.005)\end{array}$ & $\begin{array}{l}0.305 \\
(0.343)\end{array}$ & $\begin{array}{l}0.148 \\
(0.255)\end{array}$ & 1 & $\begin{array}{l}-0.019 \\
(\Delta \mathrm{L}) \\
(0.001)\end{array}$ \\
\hline \multirow[t]{2}{*}{ Serbia } & First & $\begin{array}{l}1.153 \\
(0.000)\end{array}$ & - & - & 1 & $\begin{array}{l}-0.099 \\
(\Delta \mathrm{L}) \\
(0.005)\end{array}$ \\
\hline & Second & $\begin{array}{l}1.096 \\
(0.000)\end{array}$ & - & 1 & - & $\begin{array}{l}-0.185 \\
(\Delta \mathrm{B}) \\
(0.000)\end{array}$ \\
\hline
\end{tabular}


Third

1.044

$(0.000)$
- $\quad 0.073$

$(\Delta \mathrm{M})$

$(0.751)$

The table presents only the most important results for the discussion. The rest of the results of the model are not presented here in order to save space, but are available on request. The values in brackets represent $p$-values of the coefficients.

Computed in JMulTi.

Given that we use data for Albania and North Macedonia from beginning of 2005 until mid of 2019, it could be argued that the Great depression that started in 2008 has prevented efficient interest rate transmission. In other words, a structural break may have occurred regarding the cointegrating relationships, and therefore we employ sample-split Chow test to check the parameter constancy throughout the sample period. The bootstrapped p-values of the test are displayed in Figure 2 and suggest a structural break at the beginning of 2010 for both Albania and North Macedonia, questioning the parameter constancy of the estimation explained above. Therefore, we extend our analysis for these two countries focusing on the period after the structural break.
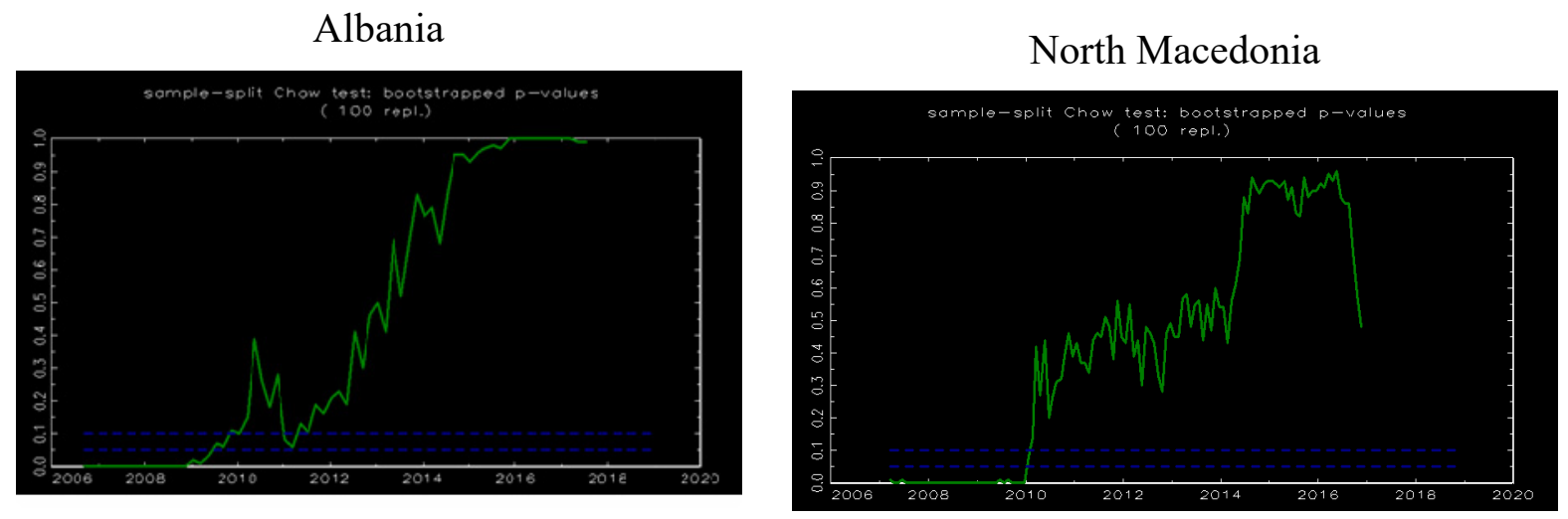

Figure 2. Bootstrapped p-values of sample-split Chow testComputed in JMulTi

The estimated results for the period after the structural break for both countries are presented in Table 3 (Note 3). In the case of Albania, three cointegrating vectors are estimated that is one vector more in comparison with the results for the whole sample which suggests that the interest rate pass-through has been weakened during the economic and financial crisis. The estimated coefficients on the monetary policy interest rate are statistically significant at 5 percent level of significance, with appropriate sign, and suggest complete pass-through which varies around one in case of money market interest rate and bank borrowing interest rate. On the other hand, it is higher than one in the case of bank lending interest rate (1.4), but still substantially lower than that estimated for the whole sample (2.2). The adjustment coefficient from the first cointegrating vector entering the equation where the change in bank lending interest rate is the dependent variable indicates that it adjusts very fast by 60.9 percent of the 
remaining disequilibrium each month to establish long-run equilibrium. The speed of adjustment is also high (61.8 percent) in the second cointegrating vector in the equation, where the change in bank borrowing interest rate is the dependent variable. On the other hand, the adjustment parameter in the third cointegrating vector entering the equation where the change in money market interest rate is the dependent variable, indicates that it adjusts very slowly by 6.8 percent of the remaining disequilibrium each month to establish long-run equilibrium.

Regarding the results for North Macedonia, the model estimates two cointegrating vectors that is one more than that obtained for the whole sample. In the first cointegrating vector where the coefficient of the bank lending interest rate is normalized to 1 , the results suggest that one percentage point increase of the monetary policy interest rate results in 1.03 percentage points increase in the bank lending interest rate in the long run, holding other things constant. The increase of the money market interest rate by one percentage point gives 1.44 percentage points increase in the bank lending interest rate in the long run, ceteris paribus. Regarding the second cointegrating vector where the coefficient of the bank borrowing interest rate is normalized to 1 , only the coefficient on money market interest rate is statistically significant at 5 percent level of significance and suggest that one percentage point increase of the money market interest rate results in 2.28 percentage points increase in the bank borrowing interest rate in the long run, holding other things constant. The speed of adjustment parameters in both cointegrating vectors are statistically significant at conventional level of significance, but they are relatively low and the sign of the coefficient in the second cointegrating vector entering the equation where the change in bank borrowing interest rate is the dependent variable is opposite than expected.

Table 3. Results from the cointegration analysis of interest rate pass-through

\begin{tabular}{|c|c|c|c|c|c|c|}
\hline \multirow{2}{*}{ Country } & \multirow{2}{*}{$\begin{array}{l}\text { Order of cointeg. } \\
\text { vector }\end{array}$} & \multicolumn{4}{|c|}{ Endogenous variables } & \multirow[t]{2}{*}{$\begin{array}{l}\text { Speed } \\
\text { adjust. }\end{array}$} \\
\hline & & $\mathrm{K}$ & M & B & $\mathrm{L}$ & \\
\hline \multirow[t]{3}{*}{ Albania } & First & $\begin{array}{l}1.408 \\
(0.000)\end{array}$ & - & - & 1 & $\begin{array}{l}-0.609(\Delta \mathrm{L}) \\
(0.000)\end{array}$ \\
\hline & Second & $\begin{array}{l}1.133 \\
(0.00)\end{array}$ & - & 1 & - & $\begin{array}{l}-0.068(\Delta \mathrm{B}) \\
(0.113)\end{array}$ \\
\hline & Third & $\begin{array}{l}0.970 \\
(0.000)\end{array}$ & 1 & - & - & $\begin{array}{l}-0.618(\Delta \mathrm{M}) \\
(0.000)\end{array}$ \\
\hline \multirow[t]{2}{*}{$\begin{array}{l}\text { North } \\
\text { Macedonia }\end{array}$} & First & $\begin{array}{l}1.031 \\
(0.000)\end{array}$ & $\begin{array}{l}1.441 \\
(0.000)\end{array}$ & - & 1 & $\begin{array}{l}-0.042(\Delta \mathrm{L}) \\
(0.014)\end{array}$ \\
\hline & Second & $\begin{array}{l}0.411 \\
(0.385)\end{array}$ & $\begin{array}{l}2.281 \\
(0.000)\end{array}$ & 1 & - & $\begin{array}{l}0.074(\Delta \mathrm{M}) \\
(0.000)\end{array}$ \\
\hline
\end{tabular}


The table presents only the most important results for the discussion. The rest of the results of the model are not presented here in order to save space, but are available on request. The values in brackets represent $p$-values of the coefficients.

Although in the multivariate approach all variables for interest rates are treated as potentially endogenous, it should be mentioned that some of the variables described in the Section 3 may be weakly exogenous since, according to economic reasoning, it is expected that the monetary policy interest rate influences the deposit market interest rate and banks' borrowing and lending interest rates. Thus, we test whether the monetary policy interest rate is weakly exogenous variable (Appendix 4). In the case of Albania, our results suggest that the adjustment coefficient of the monetary policy interest rate is restricted to zero and thus, indicates that it is a weakly exogenous variable in the second cointegrating vector where the coefficient of the bank borrowing interest rate is normalized to 1. If shorter sample (2010 -2019) is considered for Albania, the results suggest that the monetary policy interest rate is a weakly exogenous variable only with respect to money market interest rate. The results for North Macedonia suggest that the weak exogeneity is estimated only in the model for shorter sample. Namely, the adjustment coefficient of the monetary policy interest rate is restricted to zero which indicates that it is a weakly exogenous variable in the second cointegrating vector where the coefficient of the bank borrowing interest rate is normalized to 1. As for Serbia, the results suggest that the monetary policy interest rate is a weakly exogenous variable only with respect to money market interest rate. In general, our results suggest that the monetary policy interest rate may be considered as a weakly exogenous variable with respect to money market interest rate and bank borrowing interest rate, but not with respect to bank lending interest rate.

In comparative context, the results suggest more effective interest rate transmission mechanism in Albania and Serbia than in North Macedonia. Namely, the interest rate pass-through is complete to money market interest rate, bank borrowing interest rate and bank lending interest rate in both Albania and Serbia, albeit it has been weakened in Albania during the economic and financial crisis. Nevertheless, the speed of adjustment of interest rates to its long run equilibrium is much faster in Albania than in Serbia. On the other hand, the interest rate pass-through in North Macedonia is only complete to the bank lending rate. At the same time, the speed of adjustment to the long run equilibrium is slow, indicating less effective interest rate transmission.

\section{Conclusion}

This study investigated the speed and extent of the response of money market and retail interest rates to changes in the monetary policy interest rate over the period 2005-2019 for Albania and North Macedonia and over the period 2010-2019 for Serbia. We put particular emphasis on the stability of interest rate pass-through during the global economic and financial crisis. We rely on a standard error-correction model to estimate the interest rate pass-through.

Results suggest a complete interest rate pass-through in Albania, albeit it has been weakened during the economic and financial crisis. It varies around one in case of money market interest rate and bank borrowing interest rate. On the other hand, it is higher than one in the case of bank lending interest rate which might be result of relatively short sample covering 
mainly downward movement of interest rates. The relatively fast speed of adjustment indicates an effective interest rate transmission channel. In Macedonian case, the changes of the monetary policy interest rate are transmitted completely to the bank lending interest rate, albeit the speed of adjustment is relatively slow. On the other hand, the monetary policy interest rate does not affect the bank borrowing interest rate. The transmission via the money market rate has improved after the global economic and financial turmoil since both the bank borrowing interest rate and bank lending interest rate are affected by the money market interest rate changes. In the case of Serbia, the model also estimates complete interest rate pass-through indicating that the monetary policy interest rate changes are transmitted into retail rates offered by the banks to savers and borrowers in the long run. Nevertheless, the speed of adjustment is relatively slow which is still faster than in the case of North Macedonia, but much lower than the one estimated for Albania.

In general, the estimated speed and extent of the response of money market interest rate and bank retail interest rates to changes in the monetary policy interest rate gives an indication of effective interest rate transmission channel in case of Albania and Serbia. On the other hand, it is moderately effective in the case of North Macedonia given that the central bank rate changes affect mainly bank lending interest rate but not borrowing interest rate.

\section{References}

Aleksić, M., Đurđević, M., Palić, M., \& Tasić, N. (2008). Interest Rate Transmission in a Dollarized Economy: The Case of Serbia. National Bank of Serbia Working Paper No.15.

Andries, N., \& Billon, S. (2016). Retail bank interest rate pass-through in the euro area: An empirical survey. Economic Systems, 40(1). 170-194. https://doi.org/10.1016/j.ecosys.2015.06.001

Angeloni, I., Kashyap, A. K., Mojon, B., \& Terlizzese, D. (2003). Monetary policy transmission in the euro area: where do we stand? In I. Angeloni, A. K. Kashyap, \& B. Mojon (Eds.), Monetary Policy Transmission in the euro area (pp. 383-430). Cambridge: Cambridge University Press. https://doi.org/10.1017/CBO9780511492372

Besimi, F. (2009). Monetary and Exchange Rate Policy in Macedonia: Accession to the European Union. LAP Lambert Academic Publishing.

Billmeier, A., \& Bonato, L. (2002). Exchange rate pass through and monetary policy in Croatia. International Monetary Fund Working Paper No.02/109. https://doi.org/10.5089/9781451853223.001

Borstel, J. V., \& Eickmeier, S., \& Krippner, L. (2016). The interest rate pass-through in the euro area during the sovereign debt crisis. Journal of International Money and Finance, 68. 386-402. https://doi.org/10.1016/j.jimonfin.2016.02.014

Bruggemann, R., \& Lütkepohl, H. (2005). Practical problems with reduced-rank ML estimators for cointegration parameters and a simple alternative. Oxford Bulletin of Economics and Statistics, 50(5). 673-690. https://doi.org/10.1111/j.1468-0084.2005.00136.x

De Bondt, G. J. (2005). Interest rate pass-through: Empirical result for the Euro area. German Economic Review, 6(1), 37-78. https://doi.org/10.1111/j.1465-6485.2005.00121.x

Gigineishvili, N. (2011). Determinants of Interest Rate Pass-Through: Do Macroeconomic Conditions and Financial Market Structure Matter? International Monetary Fund Working 
Paper No.11/176.

Harris, R., \& Sollis, R. (2003). Applied time series: modelling and forecasting. Chichester: John Wiley \& Sons.

Hefferman, S. (1996). Modern Banking in Theory and Practice. Wiley.

Holton, S., \& d'Acri, C. R. (2015). Jagged cliffs and stumbling blocks: interest rate pass-through fragmentation during the euro area crisis. European Central Bank Working Paper No.1850.

Hristo, N., Hülsewig, O., \& Wollmershäuser, T. (2014). The interest rate pass-through in the Euro area during the global financial crisis. Journal of Banking \& Finance, 48, 104-119. https://doi.org/10.1016/j.jbankfin.2014.08.004

Istrefi, K., \& Semi, V. (2007). Exchange rate pass through in Albania: Evidence from vectors of autoregression. Bank of Albania.

Johansen, S. (1995). Likelihood-based inference in cointegrated vector autoregressive models. Oxford: Oxford University Press. https://doi.org/10.1093/0198774508.001.0001

Kapuściński, M., \& Stanisławska, E. (2018). Measuring bank funding costs in the analysis of interest rate pass-through: Evidence from Poland. Economic Modelling, 70(C), 288-300. https://doi.org/10.1016/j.econmod.2017.11.009

Kolasi, G., Shijaku, H., \& Shtylla, D. (2010). Monetary transmission mechanism in Albania. Bank of Albania.

Krstevska, A., Bojceva, T. S., Stojanova, D. B., \& Besimi, F. (2003). Exchange rate pass-through and monetary strategy of the National Bank of the Republic of Macedonia. National Bank of the Republic of Macedonia Economic Researches No. II/2003.

Kwapil, C., \& Scharler, J. (2006). Limited Pass-Through from Policy to Retail Interest Rates: Empirical Evidence and Macroeconomic Implications. Oesterreichische Nationalbank (Austrian Central Bank) Monetary Policy \& the Economy, 4, 26-36.

Liu, M. H., Margaritis, D., \& Tourani-Rad, A. (2008). Monetary policy transparency and pass-through of retail interest rates. Journal of Banking \& Finance, 32(4), 501-511. https://doi.org/10.1016/j.jbankfin.2007.06.012

Lütkepohl, H., \& Krätzig, M. (2004). Applied time series econometrics. Cambridge: Cambridge University Press. https://doi.org/10.1017/CBO9780511606885

Malile, I. (2013). Asymmetry of Interest Rate Pass-Through in Albania. Academic Journal of Interdisciplinary Studies, 2(9). https://doi.org/10.5901/ajis.2013.v2n9p539

McAdam, P., \& Morgan, J. (2001). The monetary transmission mechanism at the euro-area level: issues and results using structural macroeconomic models. European Central Bank Working Paper No.93.

Miletic, S., \& Tasic, N. (2015). Interest rate pass-through in Serbia: An asymmetric threshold cointegration analysis. Faculty of Business Economics and Entrepreneurship in Serbia.

Paries, M. D., Moccero, D. N., Krylova, E., \& Marchini, C. (2014). The retail bank interest rate pass-through the case of the euro area during the financial and sovereign debt crisis. European Central Bank Occasional Paper No.155.

Rosen, R. J. (2002). What goes up must come down? Asymmetries and Persistence in Bank 
Deposit Rates. Journal of Financial Services Research, 21(3), 173-193. https://doi.org/10.1023/a:1015085826129

Rousseas, S. (1985). A Markup Theory of Bank Loan Rates. Journal of Post Keynesian Economics, 8, 135-144. https://doi.org/10.1080/01603477.1985.11489549

Sander, H., \& Kleimeier, S. (2004). Convergence in euro-zone retail banking? What interest rate pass-through tells us about monetary policy transmission, competition and integration. Journal of International Money and Finance, 23(3), 461-492. https://doi.org/10.1016/j.jimonfin.2004.02.001

Sørensen, C. K., \& Werner, T. (2006). Bank Interest Rate Pass-Through in the Euro Area. European Central Bank Working Paper No.580.

Tanku, A., Vika, I., \& Gjermeni, M. (2007). The Role of Exchange Rate in an IT Framework, What do We Do? Bank of Albania.

Tasic, N. (2008). Exchange rate pass-through in Serbia: 2001-2007. National Bank of Serbia Working Paper No.10.

Velickovski, I. (2013). Assessing Independent Monetary Policy in Small, Open and Euroized Countries: Evidence from Western Balkan. Empirical Economics, 45(1), 137-156. https://doi.org/10.1007/s00181-012-0612-2

Vilaret, S., \& Palić, M. (2006). Exchange rate pass-through effect on prices in Serbia. National Bank of Serbia Working Paper.

Wang, K. M., \& Lee, Y. M. (2009). Market volatility and retail interest rate pass-through. Economic Modelling, 26(6), 1270-1282. https://doi.org/10.1016/j.econmod.2009.06.002

\section{Notes}

Note 1. The rest of the Western Balkan countries adopted some form of fixed exchange rate (Bosnia adopted currency board, while Montenegro and Kosovo adopted euro as an official currency) which prevented implementation of independent monetary policy and therefore, they are not part of further analysis in this paper.

Note 2. The "top-down" procedure starts from the last variable in the model and, based on the Akaike information criterion, checks if deleting it improves the specification of the model.

Note 3. We have followed the same approach in terms of specifying the lag order and determining the cointegration rank as explained previously for the model using the whole sample. The results of these tests are not presented here in order to save space, but are available on request. 
Appendices

Appendix 1. Lag length selection according to the Information criteria

\begin{tabular}{lllllll}
\hline Lag & LogL & LR & FPE & AIC & SC & HQ \\
\hline Albania & & & & & & \\
0 & -777.4384 & NA & 0.098516 & 9.033970 & 9.106878 & 9.063548 \\
1 & 4.626916 & 1518.924 & $1.40 \mathrm{e}-05$ & 0.177724 & $\mathbf{0 . 5 4 2 2 6 6 *}$ & $\mathbf{0 . 3 2 5 6 1 6 *}$ \\
$\mathbf{2}$ & 25.24694 & $\mathbf{3 9 . 0 9 4 6 2 *}$ & $\mathbf{1 . 3 3 e - 0 5 *}$ & $\mathbf{0 . 1 2 4 3 1 3 *}$ & 0.780489 & 0.390520 \\
3 & 38.47290 & 24.46421 & $1.38 \mathrm{e}-05$ & 0.156383 & 1.104193 & 0.540903 \\
4 & 49.44174 & 19.78194 & $1.46 \mathrm{e}-05$ & 0.214546 & 1.453991 & 0.717381 \\
5 & 63.70700 & 25.06728 & $1.49 \mathrm{e}-05$ & 0.234601 & 1.765679 & 0.855750 \\
6 & 68.92378 & 8.925830 & $1.70 \mathrm{e}-05$ & 0.359263 & 2.181975 & 1.098726
\end{tabular}

North Macedonia

\begin{tabular}{lllllll}
0 & -915.0802 & NA & 0.708533 & 11.00695 & 11.08163 & 11.03726 \\
1 & 296.9570 & 2351.497 & $4.26 \mathrm{e}-07$ & -3.316850 & -2.943438 & -3.165290 \\
2 & 350.2504 & 100.8426 & $2.73 \mathrm{e}-07$ & -3.763478 & $\mathbf{- 3 . 0 9 1 3 3 6 *}$ & $\mathbf{- 3 . 4 9 0 6 7 0 *}$ \\
3 & 372.9740 & 41.90945 & $2.52 \mathrm{e}-07$ & -3.844000 & -2.873128 & -3.449945 \\
4 & 389.2891 & 29.30851 & $2.51 \mathrm{e}-07$ & -3.847774 & -2.578171 & -3.332470 \\
$\mathbf{5}$ & 405.9393 & $\mathbf{2 9 . 1 1 2 9 0 *}$ & $\mathbf{2 . 5 0 e - 0 7 *}$ & $\mathbf{- 3 . 8 5 5 5 6 0 *}$ & -2.287228 & -3.219009 \\
6 & 418.1549 & 20.77389 & $2.63 \mathrm{e}-07$ & -3.810239 & -1.943177 & -3.052439 \\
Serbia & & & & & & \\
0 & -569.2970 & $\mathrm{NA}$ & 1.598476 & 11.82056 & 11.92673 & 11.86349 \\
1 & 32.78565 & 1142.095 & $9.03 \mathrm{e}-06$ & -0.263622 & 0.267247 & -0.048964 \\
2 & 95.31631 & 113.4577 & $3.47 \mathrm{e}-06$ & -1.223017 & $\mathbf{- 0 . 2 6 7 4 5 4 *}$ & $\mathbf{- 0 . 8 3 6 6 3 4 *}$ \\
3 & 110.7326 & 26.70041 & $3.52 \mathrm{e}-06$ & -1.210982 & 0.169276 & -0.652873 \\
4 & 130.3527 & 32.36296 & $3.30 \mathrm{e}-06$ & -1.285622 & 0.519330 & -0.555788 \\
5 & 143.4066 & 20.45573 & $3.55 \mathrm{e}-06$ & -1.224879 & 1.004767 & -0.323319 \\
$\mathbf{6}$ & 178.1194 & $\mathbf{5 1 . 5 3 2 3 5 *}$ & $\mathbf{2 . 4 6 e - 0 6 *}$ & $\mathbf{- 1 . 6 1 0 7 0 9 *}$ & 1.043632 & -0.537424 \\
7 & 186.4308 & 11.65312 & $2.97 \mathrm{e}-06$ & -1.452182 & 1.626854 & -0.207171 \\
\hline
\end{tabular}

* indicates lag order selected by the criterion

LR: sequential modified LR test statistic (each test at 5\% level); PE: Final prediction error; AIC: Akaike information criterion; SC: Schwarz information criterion; HQ: Hannan-Quinn information criterion.

Computed in EViews 7. 
Appendix 2. Results from the tests of cointegration rank

\begin{tabular}{|c|c|c|c|c|c|c|c|c|}
\hline \multirow[b]{2}{*}{ Method } & \multirow[b]{2}{*}{ Model } & \multirow[b]{2}{*}{$\begin{array}{l}\text { Number } \\
\text { of CVs }\end{array}$} & \multicolumn{2}{|c|}{ Albania } & \multicolumn{2}{|c|}{ North Macedonia } & \multicolumn{2}{|l|}{ Sebia } \\
\hline & & & $\begin{array}{l}\mathrm{p} \\
\text { value }\end{array}$ & $\begin{array}{l}\text { Suggested } \\
\text { number of } \\
\mathrm{CVs}\end{array}$ & $\begin{array}{l}\mathrm{p} \\
\text { value }\end{array}$ & $\begin{array}{l}\text { Suggested } \\
\text { number of } \\
\mathrm{CVs}\end{array}$ & $\begin{array}{l}\mathrm{p} \\
\text { value }\end{array}$ & $\begin{array}{l}\text { Suggested } \\
\text { number of } \\
\mathrm{CVs}\end{array}$ \\
\hline \multirow{11}{*}{$\begin{array}{l}\text { Johansen } \\
\text { trace } \\
\text { test }\end{array}$} & \multirow[t]{4}{*}{1} & 0 & 0.000 & \multirow[t]{4}{*}{2} & 0.000 & \multirow[t]{4}{*}{1} & 0.000 & \multirow[t]{4}{*}{3} \\
\hline & & 1 & 0.001 & & 0.334 & & 0.000 & \\
\hline & & 2 & 0.068 & & 0.440 & & 0.005 & \\
\hline & & 3 & 0.327 & & 0.867 & & 0.358 & \\
\hline & \multirow[t]{4}{*}{2} & 0 & 0.000 & \multirow[t]{4}{*}{2} & 0.000 & \multirow[t]{4}{*}{2} & 0.000 & \multirow[t]{4}{*}{2} \\
\hline & & 1 & 0.001 & & 0.007 & & 0.007 & \\
\hline & & 2 & 0.138 & & 0.366 & & 0.229 & \\
\hline & & 3 & 0.476 & & 0.227 & & 0.515 & \\
\hline & \multirow[t]{3}{*}{3} & 0 & 0.000 & \multirow[t]{3}{*}{2} & 0.000 & \multirow[t]{3}{*}{1} & 0.000 & \multirow[t]{3}{*}{3} \\
\hline & & 1 & 0.002 & & 0.477 & & 0.000 & \\
\hline & & 2 & 0.125 & & 0.418 & & 0.032 & \\
\hline \multirow{11}{*}{$\begin{array}{l}\text { Saikkonen } \\
\text { and } \\
\text { Lütkepohl } \\
\text { test }\end{array}$} & \multirow[t]{4}{*}{1} & 0 & 0.004 & \multirow[t]{4}{*}{1} & 0.000 & \multirow[t]{4}{*}{1} & 0.000 & \multirow[t]{4}{*}{3} \\
\hline & & 1 & 0.090 & & 0.538 & & 0.000 & \\
\hline & & 2 & 0.016 & & 0.940 & & 0.001 & \\
\hline & & 3 & 0.347 & & 0.996 & & 0.803 & \\
\hline & \multirow[t]{4}{*}{2} & 0 & 0.000 & \multirow[t]{4}{*}{1} & 0.000 & \multirow[t]{4}{*}{1} & 0.000 & \multirow[t]{4}{*}{3} \\
\hline & & 1 & 0.213 & & 0.907 & & 0.005 & \\
\hline & & 2 & 0.199 & & 0.514 & & 0.011 & \\
\hline & & 3 & 0.944 & & 0.854 & & 0.923 & \\
\hline & \multirow[t]{3}{*}{3} & 0 & 0.009 & \multirow[t]{3}{*}{1} & 0.002 & \multirow[t]{3}{*}{1} & 0.000 & \multirow[t]{3}{*}{3} \\
\hline & & 1 & 0.220 & & 0.146 & & 0.000 & \\
\hline & & 2 & 0.071 & & 0.334 & & 0.011 & \\
\hline
\end{tabular}

Computed in JMulTi 4. 
Appendix 3. Results for diagnostic tests (p-value)

\begin{tabular}{llll}
\hline & Albania & North Macedonia & Serbia \\
\hline $\begin{array}{l}\text { LM test of residual } \\
\text { autocorrelation }\end{array}$ & 0.753 & 0.998 & 0.158 \\
& & & \\
$\begin{array}{l}\text { Jarque-Bera } \\
\text { normality test }\end{array}$ & 0.000 & 0.000 & 0.000 \\
\hline
\end{tabular}

Computed in JMulTi 4.

Appendix 4. Weak exogeneity test on the adjustment coefficient of the monetary policy interest rate

\begin{tabular}{lllll}
\hline Sample & Normalization on: & Albania & North Macedonia & Serbia \\
\hline Whole & L & -0.019 & -0.067 & -0.060 \\
sample & & $(0.052)$ & $(0.000)$ & $(0.002)$ \\
& B & $*$ & $/$ & -0.102 \\
& & & & $(0.000)$ \\
& M & $/$ & $*$ \\
Shorter & L & -0.047 & -0.115 & $/$ \\
sample & & $(0.000)$ & $(0.000)$ & $/$ \\
& B & -0.047 & $*$ & $/$ \\
& & $(0.024)$ & & \\
& M & $*$ & $/$ & \\
\hline
\end{tabular}

The values in brackets represent $p$-values of the coefficients.

* The test suggests that the adjustment coefficient of the monetary policy rate is not statistically different from zero at $1 \%$ significance level.

Computed in JMulTi 4.

\section{Copyright Disclaimer}

Copyright for this article is retained by the author(s), with first publication rights granted to the journal. This is an open-access article distributed under the terms and conditions of the Creative Commons Attribution license (http://creativecommons.org/licenses/by/3.0/). 